\section{Antimicrobial Activity and Physicochemical Properties of Antibiotic Pastes Used In Regenerative Endodontics}

Rafaela Fernandes Zancan ${ }^{1} \mathbb{D}$, Bruno Cavalini Cavenago ${ }^{2} \mathbb{D}$, Denise Ferracioli Oda $^{1} \mathbb{D}$, Clovis Monteiro Bramante ${ }^{1} \mathbb{D}$, Flaviana Bombarda de Andrade ${ }^{1} \mathbb{D}$, Marco Antonio Hungaro Duarte ${ }^{1}$ (])
'Department of Restorative Dentistry, Dental Materials and Endodontics, Bauru Dental School, USP-Universidade de São Paulo, Bauru, SP, Brazil ${ }^{2}$ Department of Restorative Dentistry, UFPR-Universidade Federal do Paraná, Curitiba, PR, Brazil

Correspondence: Rafaela Fernandes Zancan, Al. Octávio Pinheiro Brisola no. 9-75, 17012-901 Bauru, SP, Brasil. Tel: +55-14-32358344. e-mail: rafaelazancan@yahoo.com.br

\begin{abstract}
The purpose of this study was to evaluate the $\mathrm{pH}$, solubility and antimicrobial action of Calcium Hydroxide Paste (CH), Double Antibiotic Paste (metronidazole+ciprofloxacin-DAP), calcium hydroxide added to DAP (CH/DAP) and Triple Antibiotic Paste (metronidazole + ciprofloxacin+minocycline-TAP). $\mathrm{pH}(\mathrm{n}=10)$ were measured by $\mathrm{pHmeter}$. Root canals of acrylic teeth $(n=10)$ were filled with the above-mentioned intracanal-dressings, immersed in ultrapure water, and solubility was measured by the difference between the initial and final volume (7,15 and 30 days) by using micro-computed tomography. Enterococcus faecalis biofilm was induced on bovine dentin disc surfaces $(n=20)$, and treated with the pastes for 7 days. Percentage bacterial viability was verified by confocal microscope, with LIVE/DEAD dye. $\mathrm{CH}$ and $\mathrm{CH} / \mathrm{DAP}$ presented the highest $\mathrm{pH}$ values. Regarding solubility, after 7 days, antibiotic groups presented significant volume loss. $\mathrm{CH}$ and $\mathrm{CH} / \mathrm{DAP}$ showed no statistical difference compared with the Control in antimicrobial action against $E$. faecalis biofilm. However, TAP and DAP presented a significant percentage reduction in bacterial population. Due to high solubility of the pastes, renewing antibiotic dressings every 7 days, or using the medications for this period in regeneration protocols is recommended. DAP is indicated for killing $E$. faecalis in biofilm because it has antimicrobial action similar to TAP. Adding Calcium Hydroxide to DAP significantly decreased its antimicrobial action. In spite of its the low solubility and high $\mathrm{pH}$ values, the $\mathrm{CH}$ paste showed a low level of antimicrobial action against $E$. faecalis in biofilm.
\end{abstract}

Key Words: calcium hydroxide, antibiotic pastes, Enterococcus faecalis, solubility, hydroxyl ions

\section{Introduction}

Pulp necrosis of immature permanent teeth is a clinical situation in endodontics associated with traumatic injuries, anatomic anomalies and caries in young patients (1). Depending on the stage of tooth development, the dentin walls may be fragile, making the tooth more susceptible to fractures (2). The open-apex also increases the chances of extravasion of irrigant solutions and filling materials being over extended, causing chemical irritation, flare ups and an inappropriate obturation seal (3).

Clinically treatments have been proposed for artificial apical closure (apexification) performed in one visit, with mineral trioxide aggregate (MTA) that induced an artificial barrier, and treatment with calcium hydroxide $(\mathrm{CH})$ in multiple-visits, which stimulated the formation of a hard tissue barrier (4). However, root development can be prevented or restricted by these techniques, leading to the risk of root canal fracture during masticatory efforts (5).

As an alternative technique, regenerative endodontic protocols (REPs) are intended to promote continued root maturation and apical closure. Local application of antibiotics as intracanal dressing has been used to eradicate endodontic pathogens during these procedures. Because of its broad spectrum of action against oral microorganisms and its ability to disinfect dentin $(6,7)$., Triple Antibiotic Paste (TAP), a combination of metronidazole, ciprofloxacin and minocycline has been widely used. Minocycline can cause tooth discoloration, but the use of only metronidazole and ciprofloxacin, called Double Antibiotic Paste (DAP), solved this problem (8). An alternative that has hardly been studied is the interaction of the antimicrobial action of DAP with the biological benefits of calcium hydroxide.

Based on the foregoing, the aim of the present study was to evaluate the $\mathrm{pH}$, percentage of volumetric loss, the antimicrobial effect of different intracanal dressings used in regenerative procedures, on mono specie (Enterococcus faecalis) biofilms. The null hypothesis tested was that the pastes would have similar values of $\mathrm{pH}$, volumetric loss and antimicrobial effect.

\section{Material and Methods Intracanal Dressings}

Four intracanal dressings were evaluated:

$\mathrm{CH}$ - CH/polyethylene glycol (Calen; SS White Artigos Dentarios Ltd, Rio de Janeiro, RJ, Brazil); DAP-Double Antibiotic Paste (Metronidazole, Ciprofloxacin)/Saline (500 
$\mathrm{mg}$ of each antibiotic/ $1 \mathrm{~mL}$ ); CH/DAP-Double Antibiotic Paste (Metronidazole, Ciprofloxacin) $/ \mathrm{Ca}(\mathrm{OH})_{2}$ ((Merck \& Co., NJ) /Saline (250 mg of each antibiotic/500 mg Ca(OH) $11 \mathrm{~mL}$ ); TAP - Triple Antibiotic Paste (metronidazole, ciprofloxacin, minocycline)/Saline (500 $\mathrm{mg}$ of each antibiotic/1 mL).

To obtain the antibiotic powders (ciprofloxacin, metronidazole and minocycline), their tablets were ground by using a pestle and mortar, and then weighed on a high precision balance.

\section{Experiment 1 and 2: $\mathrm{pH}$ of the Pastes}

The $\mathrm{pH}$ measurement test was done in two ways. In Test 1 the $\mathrm{pH}$ of the 4 pastes was measured (with a pH meter). In Test 2 we tried to simulate the $\mathrm{pH}$ of the solubilized root canal pastes in the periapical tissues. Test $1: 1 \mathrm{~mL}$ of the pastes were manipulated as described below and immersed in $10 \mathrm{~mL}$ distilled water. After being agitated for $5 \mathrm{~min}$ the solutions were measured with a $\mathrm{pH}$ meter (model 371; Micronal, São Paulo, SP, Brazil). Test 2 and 3: Based on the Duarte et al. (9) methodology, 40 acrylic teeth $(n=10)$, with an artificial foramen standardized to a diameter of $800 \mu \mathrm{m}$ were filled with the antibiotic pastes, and the crown access was sealed. Afterwards, the teeth were individually immersed in a plastic flask containing $10 \mathrm{~mL}$ of ultrapure water. After time intervals of 7, 15 and 30 days, the teeth were moved to a new plastic flask with an equal volume of new ultrapure water. The $\mathrm{pH}$ in the solutions was analyzed with a pH meter (Model 371; Micronal, São Paulo, SP, Brazil).

\section{Experiment 3: Micro-CT Volumetric Solubility}

The canals of 40 artificial maxillary central incisors fabricated of resin acrylic, with a foramen standardized to a diameter of $800 \mu \mathrm{m}$, were filled immediately after mixing the experimental pastes $(n=10)$ Subsequently, the samples were scanned using an $X$-ray desktop microfocus CT scanner (SkyScan 1174v2; SkyScan, Kontich, Belgium). The acrylic teeth were stored, individually immersed in plastic flasks containing $10 \mathrm{~mL}$ of deionized water in a warm room at $37^{\circ} \mathrm{C}$. After time intervals of 7,15 and 30 days, the acrylic teeth were removed from the flasks and scanned again. The image capture parameters used were the same for all stages: voxel size $19.70 \mu \mathrm{m} ; 0.5^{\circ}$ rotation step and $360^{\circ}$ rotation. Each scan consisted of 373.tif images with 1024 x 1304 pixels. Digital data were further elaborated by reconstruction software (NReconvl.6.4.8, SkyScan) and the volume $\left(\mathrm{mm}^{3}\right)$ of the pastes was obtained by means of CTan software (CTan v1.11.10.0, SkyScan). The solubility of each specimen was considered the difference between the initial and final volume scanning, showing the proportion of the dissolved material.
Experiment 4: Antimicrobial Test and Microscopic Analysis

Sample Preparation

Dentin blocks were obtained from bovine central incisors with fully developed roots, by using trephine drills $4.0-\mathrm{mm}$ in diameter, under abundant irrigation. The incisors were positioned laterally to provide access to the most flattened portion of the root. The root was perforated with a trephine attached to a counter-angle positioned perpendicular to the teeth passing through the mesial and distal dentin walls, thus obtaining two dentin blocks measuring $4 \mathrm{~mm}$ $x 1.2 \mathrm{~mm}$ (diameter $x$ thickness). These were adjusted by means of polishing with 500 and 800 grit SiC papers on the pulp surface to smooth it. The smear layer formed during dentin specimen preparation, was removed by submerging the specimens in 17\% EDTA for $5 \mathrm{~min}$; and after this, they were sterilized by autoclaving at $121^{\circ}$ for $20 \mathrm{~min}$.

\section{Biofilm Growth}

The microbiological procedures and manipulation of the pastes were conducted under aseptic conditions in a laminar flow chamber (VecoFlow Ltda, Campinas, SP, Brazil). For Enterococcus faecalis (E. faecalis) biofilm, $15 \mu \mathrm{L}$ standard strain (ATCC 4083) was put into $3 \mathrm{~mL}$ sterile BHI (Oxoid, Basingstoke, UK) for growth overnight at $37^{\circ}$ in air. After this, bacterial density was adjusted at 109 cells $/ \mathrm{mL}$ for $E$. faecalis (ATCC 4083) in a spectrophotometer (UV-VISIBLI, Shimadzu, Japan) at an optical density (OD) of 1 at 600 $\mathrm{nm}$ according to the 0.5 MacFarland standard.

\section{Dentin Surface Infection}

After density adjustment, the dentin surfaces were infected. For E. faecalis biofilm a dentin block $+100 \mu \mathrm{L}$ of E. faecalis $+900 \mu \mathrm{L}$ of BHI was put into each well of a 24-well multiwell plate. For biofilm growth, all plates were incubated aerobically at $37{ }^{\circ} \mathrm{C}$ for 21 days. The BHI was refreshed every 2 days.

\section{Antimicrobial Test for E. faecalis Biofilm}

After the incubation period, the infected samples were washed with $1 \mathrm{~mL}$ of distilled water to remove loosely adherent planktonic bacteria. Then they were randomly divided into four groups $(n=20)$ according to the experimental pastes +1 control group that received no treatment. The contact test was performed by immersing dentin samples for 7 days in the experimental intracanal dressings and incubating them at $37^{\circ} \mathrm{C}$.

\section{Microbiological Analysis}

Biofilm viability was analyzed by using the SYTO 9/ propidium iodide technique (Live/Dead, Baclight, Invitrogen, Eugene, OR). SYTO-9 is a green fluorescent nucleic acid 
stain that acts as a dye, generally labeling both live and dead microorganisms; and propidium iodide is a red fluorescent nucleic acid stain that only penetrates the cells with damaged membranes, signaling dead microorganisms. After the established time of contact with the pastes, the blocks were washed with phosphate-buffered saline (PBS) and stained with $15 \mu \mathrm{L}$ of the dyes for $15 \mathrm{~min}$ in a dark environment. Then they were washed again, and directly observed using an inverted confocal laser scanning microscope (Leica TCS-SPE; Leica Biosystems CMS, Mannheim, Germany). Four confocal "stacks" of random areas were obtained for each sample using a 40x oil lens. In total, there were 5 samples per group, therefore, 20 stacks for each medication. For quantification purposes, biolmage_L software (www.biolmageL.com) was used to calculate the total biovolume and the percentage of red (dead cells) found after the antimicrobial treatment.

\section{Statistical Analysis}

The data from all the analyses were subjected to the Shapiro-Wilks test to verify normality, which was shown to be absent. Then, for the global and individual comparisons, the Kruskal-Wallis and Dunn tests, respectively, were used.

The significance level was established at 5\%.

\section{Results}

Table 1 presents the $\mathrm{OH}$ - and $\mathrm{Ca} 2+$ ion release results provided by the experimental pastes in all time intervals analyzed. The $\mathrm{CH}$ and DAP/CH presented the highest values, with no statistically significant differences $(p<0.05)$ between the two. DAP and TAP showed acid pH values. $\mathrm{pH}$ measured in direct contact with the pastes showed higher $\mathrm{pH}$ values for $\mathrm{CH}-12.51, \mathrm{DAP} / \mathrm{CH}-12.36$, and lower for DAP-5.49 and TAP-4.32.

Table 2 presents the percentage of solubility of the pastes in 7, 15 and 30 days. At all periods there was high solubility with no statistically significant differences ( $p>0.05$ ) between DAP/CH, DAP and TAP. For $\mathrm{CH}$, lower values were shown $(p<0.05)$. For all groups in 30 days the volume of solubilized pastes was higher than 7 , with no statistical difference intragroup for $\mathrm{CH}(\mathrm{p}>0.05)$.

Table 3 presents the percentages of live cells in the biofilms after contact with experimental pastes. The weakest antimicrobial activity occurred in Group $\mathrm{CH}$ followed by $\mathrm{DAP} / \mathrm{CH}$, showing no statistical differences compared with the control group ( $p>0.05$ ). Groups DAP and TAP showed the best antimicrobial activity $(p<0.05)$.

Figure 1 presents micro-CT 3D reconstructions of the superimposed intracanal dressings at the root canal thirds and cross-sections in all groups.

Figure 2 presents confocal

Table 1. Medians (Med), minimum and maximum (Min-Max) values for $\mathrm{pH}$ of the pastes in different studied periods

\begin{tabular}{lcccc}
\hline & 3 days & 7 days & 15 days & 30 days \\
\hline CH & $9.52(8.6-12.3) \mathrm{Aa}$ & $8.1(7.6-9.07) \mathrm{Aab}$ & $7.9(7.4-8.15) \mathrm{ABb}$ & $8.9(7.9-11.4) \mathrm{Aa}$ \\
$\mathrm{DAP}$ & $5.3(4.8-7.2) \mathrm{BCa}$ & $6.1(5.2-6.6) \mathrm{Bab}$ & $6.2(5.9-6.6) \mathrm{BCab}$ & $5.5(4.3-6.7) \mathrm{BCb}$ \\
$\mathrm{DAP} / \mathrm{CH}$ & $9.2(8.2-10.3) \mathrm{ABa}$ & $8.85(7.8-9.76) \mathrm{Aa}$ & $8.0(7.3-8.64) \mathrm{Aab}$ & $7.1(6.5-8.0) \mathrm{ABb}$ \\
$\mathrm{TAP}$ & $5.46(4.8-7.34) \mathrm{Ca}$ & $6.17(5.29-6.54) \mathrm{Ba}$ & $6.23(5.78-6.54) \mathrm{Ca}$ & $5.39(4.4-6.6) \mathrm{Ca}$ \\
\hline
\end{tabular}

*Kruskal-Wallis with Dunn's post-hoc p-value <0.05; Different capital letters in columns indicate statistically significant intergroup differences in the same time period. laser scanning microscopy images of biofilms treated with the four intracanal dressing materials and control.

\section{Discussion}

The null hypothesis tested was rejected because the pastes presented differences in $\mathrm{pH}$,

Table 2. Median (Med), minimum and maximum (Min - Max) values of intracanal dressing volume, initial and after 7, 15 and 30 days of immersion in $10 \mathrm{~mL}$ of deionized water and the percentage of lost volume (solubility) comparing 7, 15 and 30 days volume with the initial

\begin{tabular}{|c|c|c|c|c|c|c|c|}
\hline \multirow{2}{*}{ Groups } & \multirow{2}{*}{$\begin{array}{c}\text { Initial } \\
\text { Med (Min-Max) } \\
\text { Volume }\end{array}$} & \multicolumn{2}{|c|}{$\begin{array}{c}7 \text { days } \\
\text { Med (Min-Max) }\end{array}$} & \multicolumn{2}{|c|}{$\begin{array}{c}15 \text { days } \\
\text { Med (Min-Max) }\end{array}$} & \multicolumn{2}{|c|}{$\begin{array}{c}30 \text { days } \\
\text { Med (Min-Max) }\end{array}$} \\
\hline & & Volume & $\begin{array}{c}\% \text { of lost V } \\
(7 d-I)\end{array}$ & Volume & $\begin{array}{l}\% \text { of lost V } \\
(15 d-I)\end{array}$ & Volume & $\begin{array}{l}\% \text { of lost V } \\
(30 \mathrm{~d}-\mathrm{I})\end{array}$ \\
\hline $\mathrm{CH}$ & $\begin{array}{c}9.7 \\
(8.34-11.96)^{\mathrm{A}}\end{array}$ & $\begin{array}{c}8.3 \\
(5.5-11.6)^{\mathrm{AB}}\end{array}$ & $\begin{array}{c}2.35 \\
(0-44.95)^{b}\end{array}$ & $\begin{array}{c}8.05 \\
(5.2-11.6)^{\mathrm{B}}\end{array}$ & $\begin{array}{c}5.23 \\
(1.25-47.72)^{b}\end{array}$ & $\begin{array}{c}8.05 \\
(5.2-11.3)^{\mathrm{B}}\end{array}$ & $\begin{array}{c}16,13 \\
(3,41-47.4)^{b}\end{array}$ \\
\hline DAP & $\begin{array}{c}9.8 \\
(8.21-11.3)^{\mathrm{A}}\end{array}$ & $\begin{array}{c}6.17 \\
(3.9-8.0)^{\mathrm{AB}}\end{array}$ & $\begin{array}{c}41.0 \\
(22.35-58.0)^{a}\end{array}$ & $\begin{array}{c}5.2 \\
(2.2-7.12)^{\mathrm{BC}}\end{array}$ & $\begin{array}{c}52.3 \\
(32.25-75.84)^{a}\end{array}$ & $\begin{array}{c}3.3 \\
(2.2-5.1)^{\mathrm{C}}\end{array}$ & $\begin{array}{c}65.8 \\
(51.8-75.8)^{\mathrm{a}}\end{array}$ \\
\hline $\mathrm{DAP} / \mathrm{CH}$ & $\begin{array}{c}9.7 \\
(7.4-11.5)^{\mathrm{A}}\end{array}$ & $\begin{array}{c}5.6 \\
(0.05-8.9)^{\mathrm{AB}}\end{array}$ & $\begin{array}{c}41.71 \\
(17.11-99.41)^{\mathrm{a}}\end{array}$ & $\begin{array}{c}4.1 \\
(0.05-7.71)^{\mathrm{BC}}\end{array}$ & $\begin{array}{c}57.9 \\
(31.13-99.41)^{\mathrm{a}}\end{array}$ & $\begin{array}{c}3.4 \\
(0.04-6.16)^{\mathrm{C}}\end{array}$ & $\begin{array}{c}63.5 \\
(44.99-99.4)^{\mathrm{a}}\end{array}$ \\
\hline TAP & $\begin{array}{c}10.5 \\
(8.5-12.12)^{\mathrm{A}}\end{array}$ & $\begin{array}{c}6.3 \\
(4.5-9.3)^{\mathrm{AB}}\end{array}$ & $\begin{array}{c}41.70 \\
(20.5-57.09)^{\mathrm{a}}\end{array}$ & $\begin{array}{c}6.0 \\
(0.5-8.4)^{\text {в }}\end{array}$ & $\begin{array}{c}42.31 \\
(24.3-93.38)^{\mathrm{a}}\end{array}$ & $\begin{array}{c}3.5 \\
(0.5-6.9)^{\mathrm{B}}\end{array}$ & $\begin{array}{c}63.89 \\
(39.8-93.3)^{\mathrm{a}}\end{array}$ \\
\hline
\end{tabular}

*Friedman p-value <0.05; Different capital letters in rows indicate statistically significant intragroup differences; *Kruskal-Wallis with Dunn's post-hoc p-value $<0.05$; Different lowercase letters in columns indicate statistically significant intergroup differences in the same time period. 
solubility and antimicrobial action.

As the dentin walls of infected immature teeth are fragile, the revitalization approach is the treatment that allows root development to continue, in terms of both length and thickness (5). In this method, hemorrhage is induced in the cleaned and disinfected canal space and the blood clot formed serves as a fibrin scaffold, allowing the formation of new living tissue. For effective antisepsis in root canals, care must be taken to perform the copious irrigation without extruding the irrigant; and also when performing instrumentation, because this is capable of weakening the dentin walls. For microbial control, it is necessary to place an intracanal medication with crown restoration to prevent recontamination (10).

Intracanal applications of Triple Antibiotic Paste (TAP) have been used as intracanal medication endodontics in regeneration procedures due to the broad spectrum antimicrobial activity by the combination of metronidazole, ciprofloxacin and minocycline. This has been beneficial because of the polymicrobial nature of root canal infections, (8) since TAP has been shown to be capable of eradicating anaerobic, gram-positive and gram-negative microorganisms (6). The Triple Antibiotic Paste has caused color change in teeth due to the minocycline in its formulation, which is incorporated into the tooth matrix and binds to the calcium ions via chelation, causing the discoloration (11). Thus, the use of metronidazole and ciprofloxacin only - called a Double Antibiotic Paste (DAP) was tested. Hoshino clarified the antibacterial effect of a mixture of antibiotics (TAP) in 1996 (6) but the efficacy of each agent alone needed to be studied, to investigate the real necessity of the mixture. Some studies have shown no difference between antimicrobial activity of DAP and TAP, which significantly reduced the viability of cells in a biofilm $(12,13)$ according to the results of these studies.

$\mathrm{CH}$ is known to amplify release of the growth factor (TGF- $\beta 1$ ), which modulates pulpal stem cell migration,

Table 3. Median and minimum and maximum values of the percentage of live cells of $E$. faecalis biofilm after contact with the experimental medicaments for a week

\begin{tabular}{lc}
\hline Group & \% live cells \\
\hline Control & $75.59(42.9-96.54) \mathrm{A}$ \\
$\mathrm{CH}$ & $44.64(4.08-92.03) \mathrm{A}$ \\
DAP & $0.05(0.0-31.56) \mathrm{BC}$ \\
DAP/CH & $59.98(11.46-80.33) \mathrm{AB}$ \\
TAP & $0.06(0.001-1.23) \mathrm{C}$ \\
\hline
\end{tabular}

Kruskal-Wallis with Dunn's post-hoc p-value $<0.05$; On \% of live cells, different capital letters in columns indicate statistically significant intergroup differences in the same biofilm. proliferation, and differentiation, and has been shown to be beneficial for regenerative endodontic therapies.(14). It is also preferred for the survival of stem cells from apical papilla when compared with antibiotic pastes used in high concentrations $(15,16)$. However, it may be ineffective for killing E. faecalis in biofilm, a species commonly used for microbiological tests in endodontics (Table 3). The presence of microorganisms and their antigens has a profound effect on the final phenotype of stem cells transferred to root canals during REPs (17). Thus, the presence of residual bacteria that lead to periapical and intracanal inflammation has been a major risk to the success of this therapy (18). Further antimicrobial tests are necessary with other bacterial species found in immature teeth to evaluate the antimicrobial action of $\mathrm{CH}$ in REPs.

Therefore, the purpose of using $\mathrm{CH}$ associated with DAP was to associate their biologic and antimicrobial action, respectively, as suggested by Maniglia-Ferreira (19). The $\mathrm{pH}$ measurements in direct contact with these pastes showed an acid $\mathrm{pH}$, which may have had a demineralizing effect on dentin (2). DAP/CH, showed the highest $\mathrm{OH}$ - ion release favoring an alternative biological approach, with no statistical difference when compared with the alkaline $\mathrm{CH}$ paste. However, instead of any increase in antimicrobial activity, the association of $\mathrm{CH}$ to the DAP had the same behavior as that of $\mathrm{CH}$ alone in the antibacterial action against $E$. faecalis, without differing from the Control (Fig. 2). The alkaline environment provided by $\mathrm{CH}$ could probably influence the permeability of the antibiotic into the bacterial cells. Thus, this combination is unnecessary and should be avoided. Maniglia-Ferreira (19) found that $\mathrm{CH}$ did not alter the antimicrobial effects of DAP, but these conflicting results may be due to the different methodologies; in the present study the antibacterial action was tested in a biofilm model, and the above-mentioned study used the radial diffusion method in agar that involved planktonic cells.

The solubility of pastes was measured based on a novel methodology using microcomputed tomography to produce their volumetric losses in the different time intervals (20). Acrylic teeth with standardized root canals and foraminal diameter of $600 \mu \mathrm{m}$ were used to simulate immature teeth. $\mathrm{CH}$ paste had the lowest solubility values. However, approximately $40 \%$ of the antibiotic pastes were solubilized in 7 days and 65\% in 30 days (Fig. 1). The favorable outcomes of the treatment depend on effective antisepsis of the root canal. In the antimicrobial test, the DAP and TAP in the period of contact analyzed (7 days) showed the highest level of antimicrobial activity, demonstrating that 1 week was sufficient to promote effective antibacterial action. High solubility leads to a higher ionic dissociation of the molecules of intracanal pastes, which can favor 
antimicrobial properties such as $\mathrm{OH}$ - ion release from the Calcium Hydroxide paste (20). Antibiotics induce bacterial cell death by physical or chemical interaction between a drug molecule and its bacterial-specific target. Nevertheless, the high percentage of volume loss found in
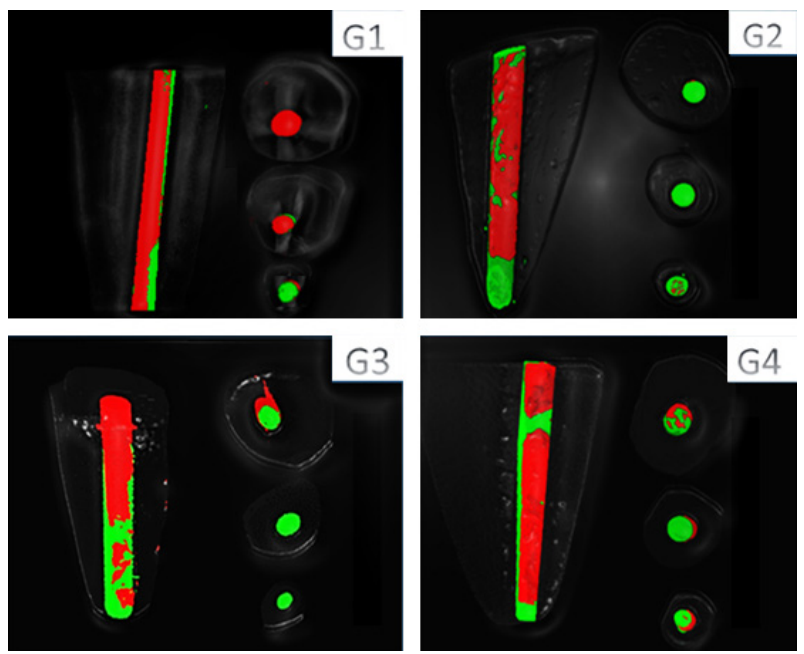

Figure 1. Representative micro-CT 3D reconstructions of the initial $\dot{\Xi}$ (gree in root canals and cross-sections at the coronal (c), middle (m), and
apical (a) thirds. G1: CH, G2: DAP, G3:DAP/CH, G4:TAP. solubility test of antibiotic pastes may lead to an empty root canal, blocking their direct contact with bacteria and consequently their antimicrobial action.

Furthermore, when the volume of water in the mixture of pastes was increased, higher solubility was observed (21). At present, there are no defined protocols for endodontic regeneration. Recommendations of the American Association Endodontics (AAE), namely "Considerations for regeneration procedures" based on clinical evidences and recent articles, have indicated that the placement of an intracanal dressing with $\mathrm{CH}$ or TAP in the patient first appointment, with the treatment time required varying between 1-4 weeks, depended on patient's signs and symptoms (22). The proportion of powder/liquid in regenerative procedures varies in concentration of up to a million-fold (0.001-1000 mg/ $\mathrm{mL}$ ) (23). Due to the high solubility, in cases of low medication concentration, the root canal is probably empty for the greater part of time, in periods longer than 7 days. Thus, in regeneration protocols it is important to consider renewing antibiotic pastes every 7 days, or using the medication for this period, and thereby induce clot formation. The DAP is indicated because it has a percentage of bacterial reduction similar to that of TAP at 7 days.
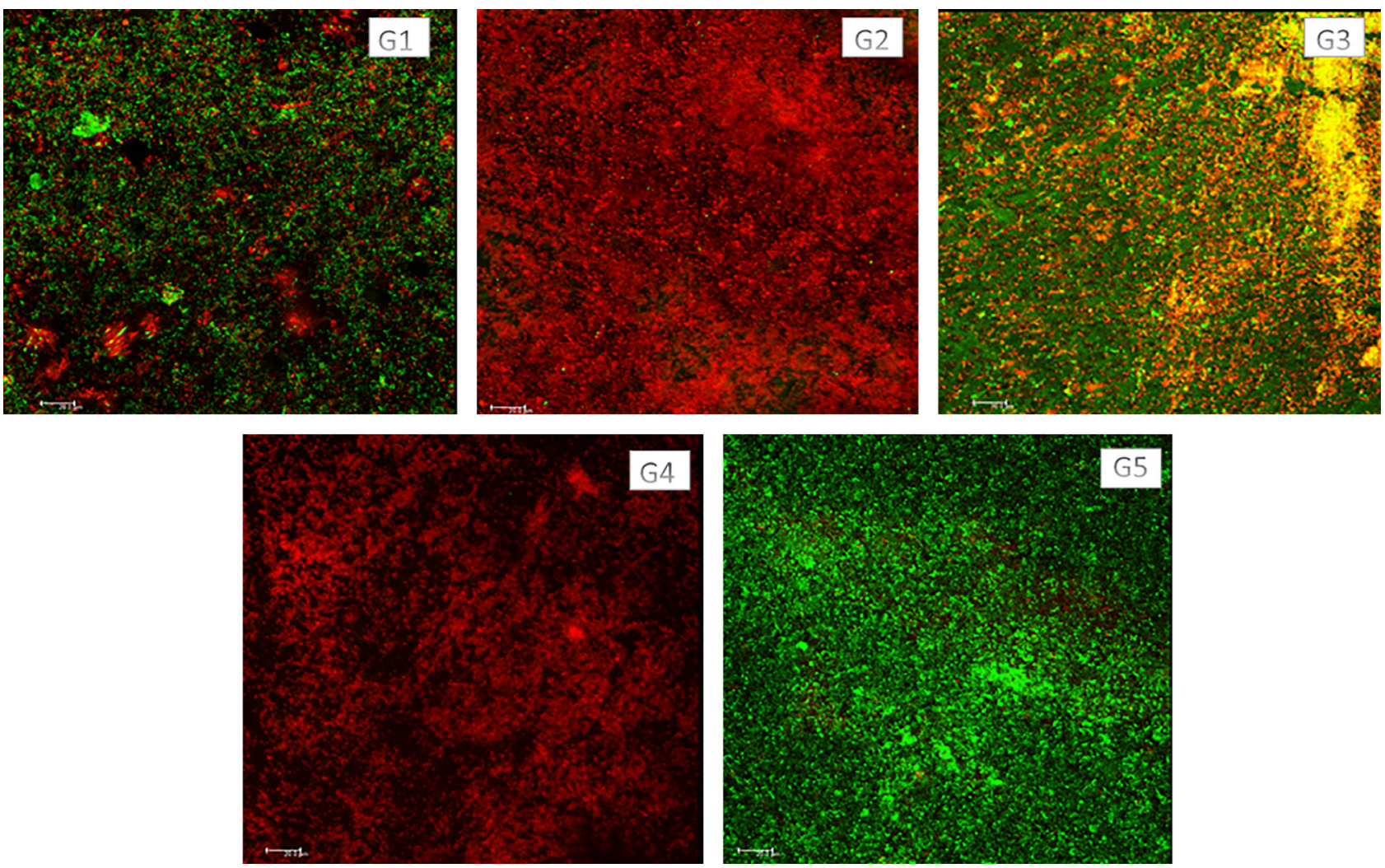

Figure 2. Confocal laser scanning microscopy of biofilms treated with CH (G1), DAP (G2), DAP/CH (G3), TAP (G4) and control (G5). Live cells are seen in green, and dead cells are seen in red. Each picture represents an area of 275 x $275 \mu \mathrm{m}$. 


\section{Resumo}

A proposição deste estudo foi avaliar o pH, solubilidade e ação antimicrobiana da pasta de Hidróxido de Cálcio (HC), Pasta Diantibiótica (metronidazol+ciprofloxacina-DAP), Hidróxido de Cálcio adicionado a DAP (HC/DAP) e pasta Triantibiótica (metronidazol + ciprofloxacina + miociclina - TAP). a medição do pH e liberação de íons cálcio $(n=10)$ foram avaliadas através de peagômetro e espectofotômetro de absorção atômica. Canais de dentes de acrílico $(n=10)$ foram preenchidos com as medicações de canal mencionadas, imersos em água ultrapura e a solubilidade foi aferida pela diferença entre o volume inicial e final (7,15 e 30 dias) usando micro tomografia computadorizada. 0 biofilme de Enterococcus faecalis foi induzido em blocos de dentina bovina $(n=20)$ e tratados com as pastas em questão por 7 dias. A porcentagem de bactérias vivas foi verificada usando o microscópio confocal com corante LIVE/DEAD. $\mathrm{HC}$ e HC/DAP apresentaram os maiores valores de $\mathrm{pH}$ e liberação de ions cálcio. A respeito da solubilidade, depois de 7 dias, os grupos com pastas antibióticas apresentaram perda de volume significante. $\mathrm{HC} \mathrm{e} \mathrm{HC/}$ DAP não tiveram diferenças estatisticas com o grupo controle na ação antimicrobiana contra biofilme. No entanto, a TAP e a DAP mostraram porcentagem significante de redução bacteriana. Conclusões: Devido à alta solubilidade das pastas, renovar as medicações antibióticas a cada 7 dias ou usa-las por esse periodo em protocolos regenerativos é recomendado. DAP é indicada para matar E. faecalis na forma de biofilme porque tem ação antimicrobiana similar a TAP. A adição do $\mathrm{CH}$ à DAP reduz significantemente sua ação antimicrobiana. Apesar da baixa solubilidade e altos valores de $\mathrm{pH}$, a pasta de $\mathrm{CH}$ apresenta baixa ação antimicrobiana contra E. faecalis em biofilme.

\section{Acknowledgements}

Supported by the State of São Paulo Research Foundation (FAPESP 2014/17473-1 and 2016/25133-1).

\section{References}

1. Hecova $H$, Tzigkounakis $V$, Merglova $V$, Netolicky J. A retrospective study of 889 injured permanent teeth. Dent Traumatol 2010;26:466475.

2. Yassen GH, Chu TM, Eckert G, Platt JA. Effect of medicaments used in endodontic regeneration technique on the chemical structure of human immature radicular dentin: an in vitro study. J Endod 2013;39:269-273.

3. Felippe WT, Felippe MC, Rocha MJ. The effect of mineral trioxide aggregate on the apexification and periapical healing of teeth with incomplete root formation. Int Endod J 2006; 39:2-9.

4. Hargreaves KM, Diogenes A, Teixeira FB. Treatment options: biological basis of regenerative endodontic procedures. J Endod 2013;39:S30-43.

5. Nazzal H, Duggal MS. Regenerative endodontics: a true paradigm shift or a bandwagon about to be derailed? Eur Arch Paediatr Dent 2017;18:3-15.

6. Hoshino E, Kurihara-Ando N, Sato I, Uematsu H, Sato M, Kota K, et al. In-vitro antibacterial susceptibility of bacteria taken from infected root dentine to a mixture of ciprofloxacin, metronidazole and minocycline. Int Endod J 1996;29:125-130.

7. Taneja $S$, Kumari M. Use of triple antibiotic paste in the treatment of large periradicular lesions. J Investig Clin Dent 2012;3:72-76.

8. Sabrah AH, Yassen GH, Spolnik KJ, Hara AT, Platt JA, Gregory RL.
Evaluation of residual antibacterial effect of human radicular dentin treated with triple and double antibiotic pastes. J Endod 2015;41:10811084.

9. Duarte MA, Midena RZ, Zeferino MA, Vivan RR, Weckwerth $P H_{\text {, }}$ Dos Santos $F$, et al. Evaluation of $\mathrm{pH}$ and calcium ion release of calcium hydroxide pastes containing different substances. J Endod 2009:35:1274-1277.

10. Yassen GH, Sabrah AH, Eckert GJ, Platt JA. Effect of different endodontic regeneration protocols on wettability, roughness, and chemical composition of surface dentin. J Endod 2015;41:956-960.

11. Tanase S, Tsuchiya H, Yao J, Ohmoto S, Takagi N, Yoshida S. Reversedphase ion-pair chromatographic analysis of tetracycline antibiotics. Application to discolored teeth. J Chromatogr B Biomed Sci Appl 1998;706:279-285

12. Sabrah AH, Yassen GH, Gregory RL. Effectiveness of antibiotic medicaments against biofilm formation of Enterococcus faecalis and Porphyromonas gingivalis. J Endod 2013;39:1385-1389.

13. A Algarni A, H Yassen G, L Gregory R. Inhibitory effect of gels loaded with a low concentration of antibiotics against biofilm formation by Enterococcus faecalis and Porphyromonas gingivalis. J Oral Sci 2015;57:213-218.

14. Galler KM, Buchalla W, Hiller KA, Federlin M, Eidt A, Schiefersteiner $M$, et al. Influence of root canal disinfectants on growth factor release from dentin. J Endod 2015;41:363-368.

15. Ruparel NB, Teixeira FB, Ferraz CC, Diogenes A. Direct effect of intracanal medicaments on survival of stem cells of the apical papilla. J Endod 2012;38:1372-1375.

16. Althumairy RI, Teixeira FB, Diogenes A. Effect of dentin conditioning with intracanal medicaments on survival of stem cells of apical papilla. J Endod 2014;40:521-525.

17. Diogenes $A$, Hargreaves KM. Microbial modulation of stem cells and future directions in regenerative endodontics. J Endod 2017;43:S95-s101.

18. Verma $P$, Nosrat A, Kim JR, Price JB, Wang $P$, Bair E, et al. Effect of residual bacteria on the outcome of pulp regeneration in vivo. J Dent Res 2017;96:100-106.

19. Maniglia-Ferreira C, de Almeida-Gomes F, Pinto MM, de Sousa Barbosa $\mathrm{FT}$, de Farias Filho DM, Albuquerque NL. In vitro evaluation of the antimicrobial effects of different intracanal medications in necrotic immature teeth. European archives of paediatric dentistry. Eur Arch Paediatr Dent 2016;17:251-255.

20. Zancan RF, Vivan RR, Milanda Lopes MR, Weckwerth PH, de Andrade FB, Ponce JB, et al. Antimicrobial activity and physicochemical properties of calcium hydroxide pastes used as intracanal medication. J Endod 2016;42:1822-1828.

21. Fridland $M$, Rosado R. Mineral trioxide aggregate (MTA) solubility and porosity with different water-to-powder ratios. J Endod 2003;29:814817.

22. Endodontists AAo Regenerative endodontics: considerations for regenerative procedures. Available from: http://www.aae.org/ regeneration. Latest access: August 2019.

23. Diogenes AR, Ruparel NB, Teixeira FB, Hargreaves KM. Translational science in disinfection for regenerative endodontics. J Endod 2014;40:S52-S57. 